\title{
Az Általános FORgALMI ADó ÉS A TÁRSASÁGI ADÓ HATÁSA A KÍNAI MÜKÖDŐTŐKE-BEÁRAMLÁSRA KöZÉP-KELET-EURÓPÁBAN ${ }^{2}$ The ROLE OF TRADE OPENNESS IN THE CHINESE INWARD FDIIN CENTRAL AND EASTERn Europe
}

A publikáció célja annak a megértése, hogy a Közép-Kelet-Európában meglévő kínai befektetések volumene mennyire függvénye a meglévö adórendszer vonásainak. A különbözö adóparadicsomokban befektetett kínai tőke nem számít ritka jelenségnek, azonban az elmúlt idöszakban a tökeinvesztíció eltolódni látszik a magasabb adóterheket kivetö fejlett világ felé. A tanulmányban bemutatott eredmények arra engednek következtetni, hogy az EU-ban és a világban zajló adócsökkentési hullám nem éri el a kívánt hatást a tökevonzó képesség erősitésében. A korrelációs analízis nem mutatott ki összefüggéseket a különbözö adónemek (általános forgalmi adó, társasági adó), valamint a kínai müködőke-állomány közt. Észtország, Magyarország és Szlovákia ebben a tekintetben kivételnek számítanak, mivel ezekben az országokban érvényes korrelációs kapcsolat állt fenn, ugyanakkor a régió többi pontján a jelenlegi adórendszer nincs hatással a kínai befektetési döntésekre.

The aim of the study is to understand how much the volume of Chinese investment depends on the features of the existing tax system in Central Eastern Europe. China's capital invested in various tax havens is not a rare phenomenon but nowadays it seems that there is a shift to the developed world with a higher tax burden. The results presented in this study suggest that the tax cuts in the EU and in the world does not have the desired effect on strengthening the ability to attract foreign capital. The correlation analysis did not reveal any relationship between the different tax types (value added tax, corporate tax) and Chinese FDI stock. In this regard Estonia, Hungary and Slovakia are exceptions as a relationship is visible in these countries but the current tax system has no impact on China's investment decisions in the region.

$1 \mathrm{PhD}$ hallgató, Pécsi Tudományegyetem Közgazdaságtudományi Kar Regionális Politika és Gazdaságtan Doktori Iskola 


\section{BEVEZETÉS}

Az elmúlt évek során a közép-kelet-európai országok többek között különböző fiskális eszközökkel tettek kísérletet tőkevonzó képességük erősítésére. A befektetések stimulálása érdekében biztosított adókedvezmények felgyorsították ugyan az FDI mértékét, azonban kérdés, hogy az erodálódó társasági adókulcsok és az így kialakult adóverseny mennyire van jótékony, illetve káros hatással az EU gazdaságára nézve. A szakirodalom előszeretettel foglalkozik az adózás és a külföldi befektetések vizsgálatával, mely során megpróbál válaszokat találni arra vonatkozóan, hogy az adóverseny, vagy az adóharmonizáció szolgálja-e jobban az egyes országok érdekeit. Az adópolitika egy érzékeny terület az egyes kormányok és a gazdaság szereplői számára. Alapvető célja, hogy biztosítsa a költségvetés bevételeit, ugyanakkor a túlzott adóztatás negatívan hat a működötőke-beáramlásra.

Kína esetében közismertek az adóparadicsomokba történő befektetések ${ }^{3}$, de a csak adózási célból végrehajtott invesztíciók jelentősége csökkenőben van. A pénzeszközök ilyen irányú átcsoportosítása miatt a fejlett világ is egyre jelentősebben részesül a kínai tőkéből. Adóharmonizáció hiányában az egyes vállalkozásoknak többletköltségekkel kell szembesülniük annak érdekében, hogy alkalmazkodni tudjanak a célországok adózási rendszeréhez. Más, egyéb felmerülő problémákkal is meg kell küzdeniük, mivel számolniuk kell a kettős adóztatás intézményrendszerével, a határon átnyúló veszteségelhatárolás problémáival és a transzferárak okozta nehézségekkel is.

Az adópolitika és a kínai tőkebefektetések kapcsolatának vizsgálatát megkönnyíti az a tény, hogy az országok adatai az EU-tagság miatt teljes mértékben összevethetők és alapvetően hasonló jogi keretek vonatkoznak a külföldi befektetőkre. Külföldi tulajdonosi részarány egy vállalkozásban akár 100 százalékig lehetséges, tehát lényegében nincs akadálya a kínaiak teljes tulajdonlásának. Teljesen szabad a tőkebehozatal, a nyereségés tőketranszfer, így adminisztrációs korlátok híján elviekben egyedül az egyes országok tőkevonzó képessége szabhat gátat a kínai tőkeimportnak.

$\mathrm{Az}$ adóharmonizáció kihívásokkal terhes feladat, mivel 28 tagállam adórendszerét kell egységessé tenni. Az adózási rendszer bonyolultsága és átláthatatlansága szükségessé teszi az erre való törekvéseket. A megfelelő harmonizációs folyamatok hiánya veszélyezteti az EU versenyképességét, ezért a harmonizált környezet kialakítását a Közösség alapvető feladatának tekinti. Minél egységesebb az EU adórendszere, annál jobban beszükül az egyes országok fiskális mozgástere, következésképpen az adóverseny által nyújtott előnyök kihasználatlanok maradnak. A teljes adóharmonizáció esetén (közös adókulcs, egységes kalkuláció) az egyes országok lényegében feladják az adóversenyből származó előnyöket, így az alacsonyabb adókulcsokat alkalmazó államoknak sérül a tőkevonzó képessége. Az Európai Unió elsősorban azért ragaszkodik az adóharmonizációhoz, mert így elkerülhető az áruk, szolgáltatások, a munkaerő és a tőke szabad mozgásának korlátozása.

3 Brit Virgin-szigetek, Kajmán-szigetek. 
$\mathrm{Az}$ adókedvezmények intézménye is rendkívül fontos tényezőnek számít a befektetőknél, azonban az adóösztönzők túlzásba vitt használata torzíthatja a piacot és indokolatlan versenyelőnyt jelenthet, mely összességében káros hatásokkal járna a Közösség egészére nézve. A külföldi müködőtőkéért folyó rivalizálás során az adózással kapcsolatos könnyítés az egyik legfontosabb eszköz, amivel a kormányok széles körben élnek is. Megnyugtató válasz talán soha nem születik arra vonatkozóan, hogy hol húzódik meg a határ az egészséges és a káros adóverseny között, mindenesetre a témakör jelentősége miatt a kérdést közösségi szinten kell kezelni.

\section{SZAKIRODALMi ÁtTEKINTÉS}

Az adózás rendkívül fontos tényező a befektetési kérdések eldöntésében, ennek ellenére limitált azoknak a szakmai írásoknak a száma, melyek a kínai tőke vizsgálatát tüzték ki célul az egyes adókulcsok változásainak függvényében. Általában véve viszont az adózás és a müködőtőke-befektetések kapcsolatát viszonylag terjedelmes szakirodalom tárgyalja. Az FDI tekintetében a szakemberek elsősorban a társasági adó szerepét hangsúlyozzák, az ÁFA és az egyéb közterhek relevanciáját kevésbé tárgyalják.

Bellak és Leibrecht a társasági adó szerepét vizsgálta a külföldi tőkebefektetésekre vonatkozóan Közép-Kelet-Európában ${ }^{4}$ [Bellak-Leibrecht, 2005]. Megállapították, hogy a túlzott adóteher negatívan hat a külföldi beruházásokra, de a kedvezőtlen hatásnak önmagában nincs akkora jelentősége, mert a befektetők más egyéb, fontosabb tényezők alapján hozzák meg döntéseiket.

Grzegorczyk és Budzynski szintén a társasági adó szerepét vizsgálta a visegrádi országokban [Grzegorczyk-Budzynski, 2015]. A szerzők meglátása szerint a vonzóképességet jelentő fontosabb elemek közül kiemelkedik a piacméret, a munkaerő költsége és minősége, a gazdasági nyitottság, a földrajzi távolság, a kockázat, a korrupció és az adózás mértéke. Ellentétben az általános forgalmi adóval - mely adónemben mára érvényesültek az adóharmonizáció szabályai - a társasági adó vonatkozásában különbségek mutatkoznak a visegrádi országok között. Az így kialakult adóverseny ellenére az alacsonyabb társasági adó nem számított releváns tényezőnek a külföldi befektetések szempontjából.

Popovici a közép-kelet-európai régió viszonyait vizsgálva szintén nem talált egyértelmü összefüggést az adóterhek és az FDI között ${ }^{5}$ [Popovici, 2012]. A makroökonómiai stabilitás, az infrastruktúra és az intézményi környezet fontosabb tényezőnek számít a régióban. Bulgáriát leszámítva az összes országnál elmondható, hogy a növekvő adóterhek nem jelentenek akadályt az FDI számára. Ez egyrészt azt is jelentheti, hogy a befektetők késve reagálnak a fiskális politika változására, másrészt viszont a gyakorlatban az adózásnak nincs akkora szerepe, mint amekkorát a globális szakirodalom megállapításai alapján előzetesen várni lehetett. A szerző eredményei a második lehetőséget 
támasztják alá, hangsúlyozva azt a tényt, hogy más tényezőknek nagyobb szerepük lehet a külföldi tőkebeáramlás alakulásában.

Hansson és Olofsdotter az EU-27 vonatkozásában vizsgálta a társasági adó mértékének hatását a külföldi müködötőke-beáramlás függvényében ${ }^{6}$ [Hansson-Olofsdotter, 2010]. Vizsgálataik során kitértek az újonnan csatlakozó államok helyzetére is és megállapították, hogy az EU-27 országaiban meglévő különböző adókulcsok javíthatnak a tőkevonzó képességükön. Az EU-15 esetében a társasági adó kevésbé játszott jelentős szerepet, tehát magasabb adókulccsal is képesek tőkét vonzani, míg a Közösség nemrégen csatlakozott országainak mérsékelniük kell az adóterheken, amennyiben versenyképesek kívánnak maradni.

Kersan-Skabic kutatása témájául a délkelet-európai országok tőkevonzó képességét választotta, mely során külön elemezte az FDI flow és stock változókat is ${ }^{7}$ [Kersan-Skabic, 2015]. A tanulmányban bemutatott eredmények arra engednek következtetni, hogy az FDI stock és a társasági adó között szignifikáns a kapcsolat, ugyanakkor az FDI flow esetében ugyanez már nem igazolódott. Mindezek ellenére más egyéb makrogazdasági tényezőknek sokkal nagyobb szerepük van a befektetési döntésekben (piacméret, gazdasági növekedés, egy före jutó GDP, bérszínvonal). Megfelelő makroökonómiai és intézményi háttér nélkül az alacsony adóteher nem elégséges a nagyobb volumenű müködötőke-beáramlás eléréséhez. A szerző úgy véli, hogy az alacsony társasági adó csak egy olcsó próbálkozásnak hat a tőkevonzó képesség erősítésében, mely mögött számtalan rejtett probléma húzódik meg (tulajdonjogok védelme, lassú adminisztráció, törvénykezés, hatékonytalanság, korrupció).

Sedmihradsky és Klazar a közép-kelet-európai régióban meglévő adóversenyt tanulmányozta [Sedmihradsky-Klazar, 2002]. Meglátásuk szerint az adóverseny nem befolyásolta az adóbevételek alakulását, nem veszélyeztette a költségvetést, viszont elösegítette az FDI beáramlást, mely jótékony hatással volt a gazdasági növekedésre. A befektetés-ösztönzés rendkívül hatékony eszköze tud lenni a külföldi tőkebeáramlásnak, azonban az adók ideiglenes mérséklése, vagy eltörlése önmagában nem elégséges feltétele a külföldi szerepvállalásnak. Az ösztönzők alkalmazása akkor lehet igazán hatékony, ha a magas hozzáadott értéket előállító iparágak, vagy a környezetkímélő termelés felé irányítják. Összességében úgy látják, hogy alkalmazásuk akkor nem jár veszéllyel, ha ésszerü keretek között, célirányosan, diszkriminációmentesen és az átláthatóságot figyelembe véve használják fel ${ }^{8}$.

Beyer kutatásának középpontjában az átmeneti országokban alkalmazott adóösztönzők hatékonysága állt [Beyer, 2002]. Az eredményei azt sugallják, hogy a befektetők számára rendkívül előnyös ösztönzők és az FDI között szignifikáns kapcsolat nem mutatható ki. Ez a tény azt mutatja, hogy a külföldi befektetésekre szánt támogatások hatékonytalannak bizonyultak. Ettől függetlenül ez nem jelentette azt, hogy a befektetők figyelmen kívül hagyták volna a politikai döntéseket, mivel a jogi környezet, a hatékony

6 1995-2006

7 2000-2011

8 Törvényes tevékenységek támogatása, ipar ösztönzése, elmaradt régiók felzárkóztatása, hatóságok bevonása. 
privatizáció, a cégek nagyobb mozgásterének engedélyezése, a relatíve alacsony társasági és jövedelemadó is fontos szerepet játszanak.

Garcimartín, Garrido és Anchuelo kutatásának tárgya szintén az adóösztönzők vizsgálata volt [Garcimartín-Garrido-Anchuelo, 2011]. Közép-Kelet-Európára vonatkozó tanulmányukban a közvetlen és a közvetett hatásokat is érintették. Kétértelmü megállapításra jutottak, mivel az adóterhek negatívan hatnak az FDI beáramlásra, viszont egy magasabb szinten megvalósuló adózás segíti a korszerűbb intézményrendszer kiépítését, mely a külföldi befektetések elengedhetetlen feltétele. Az állam adóbevételeinek csökkenése könnyen kontraproduktív lehet, mivel megfelelő források hiányában sérülhet a tőkevonzó képesség erősítésére irányuló törekvés.

Clausing és Dorobantu az EU-csatlakozás előtt álló országok lehetőségeit vizsgálta a tőkevonzó képesség fejlődésének szempontjából ${ }^{9}$ [Clausing-Dorobantu, 2005]. A szerzők arra a következtetésre jutottak, hogy már önmagában a kandidálás is jelentős hatással volt a külföldi befektetésekre. Arra is fény derült, hogy a magasabb adókulcsokat alkalmazó országokban a külföldi tőkeáramlás hátrányt szenved. A régebben csatlakozott országokkal összehasonlítva a kutatás rámutatott, hogy a közép-kelet-európai régióban a befektetők érzékenyebben reagálnak a munkaerő költségeinek és az adóterheknek negatív irányba történő változásaira.

Egger és Raff 43 országban elemezte az adóverseny és az FDI kapcsolatát ${ }^{10}$ [EggerRaff, 2011]. A vizsgált időszak során a társasági adókulcsok mérséklődtek, de az adóalap szélesebbé vált ${ }^{11}$, mely lényegében az értékcsökkenéssel járó kedvezmények fokozatos csökkentését jelentette. A konklúzió úgy fogalmazható meg, hogy ezek az intézkedések összhangban állnak a külföldi müködőtőkéért folytatott, egyre élesebbé váló versennyel.

Woodward és szerzőtársai tanulmányának középpontjában a közép-kelet-európai országok adórendszere és az FDI kapcsolata állt ${ }^{12}$ [Woodward et al., 2000]. Az adókedvezmény és a külföldi működőtőke kapcsolata statisztikailag szignifikánsnak bizonyult. A célország kiválasztásában a kedvező adózás hatással volt a befektetők döntéseire, következésképpen a magasabb adóterhek alkalmazása nem célszerü a tôkehiánnyal rendelkező államokban. Az adózás tehát kétségtelenül fontos mutató, azonban egyes tényezők még ennél is relevánsabb szerepet játszanak a tőkevonzó képesség erősítésében. A különböző ösztönzők sem képesek ellensúlyozni a kevésbé fejlett piaci viszonyokat és a politikai kockázatot.

Korniyenko és Sakatsume az átmeneti országban megvalósult kínai beruházásokat kutatta [Korniyenko-Sakatsume, 2009]. Tanulmányukban a külföldi befektetések egyik legfontosabb hajtóerejének a kedvező adózást írják le. Kínában a hazai invesztíciók esetében az adókulcsok rendkívül magasak, ezért bizonyos esetekben a kínaiak külföldön befektetett pénzüket visszaforgatják az anyaországba, mivel a külföldi befektetésekre kisebb az adóteher ${ }^{13}$. A kezdeti tőkeexport elsősorban adóparadicsomok és Kínához

9 1992-2001

$101982-2005$

$11 \mathrm{Az}$ adó alapját jelentő tételek szélesítése.

12 1990-1993

13 Például Kínában megvalósult hongkongi befektetések, melyek mögött kínai cégek állnak. 
közeli országok felé irányult, de ma már a kínai FDI a világ más pontjain is jelentős mértékben képviselteti magát, főként az iparosodott és a fejlődő országokban (Afrika, átmeneti országok).

A European Union Chamber of Commerce in China által kiadott felmérés az Európai Unióban tevékenykedő kínai befektetők meglátásait összegezte [European Union Chamber of Commerce in China, 2013]. A különböző vélemények alapján elmondható, hogy az EU-ban az adórendszer és az ösztönzők releváns szerepet töltenek be a befektetési döntésekben ${ }^{14}$, azonban az adózás nem az egyetlen szempont, amit a kínaiak figyelembe vesznek ${ }^{15}$. A kutatásban részt vevő kínaiak az ösztönzők típusai közül leginkább az adózással kapcsolatos könnyítések meglétét látnák szívesen és a cégek egybehangzóan állították, hogy kisebb adóteher további befektetéseket hozna Kínából. Mindezek mellett a kínaiak hiányolják a szakmai segítséget is, mely segíti őket a helyi adótörvények értelmezésében ${ }^{16}$. Más régiókkal összehasonlítva az EU a kínaiak számára rendkívül bonyolult szervezet benyomását kelti, mivel az egyes országok adónemei nem minden esetben harmonizáltak, ezért a befektetőknek eltérő szabályozáshoz kell alkalmazkodniuk $^{17}$.

Ebbers és Zhang az EU-ban meglévő kínai befektetéseket vizsgálta, elsősorban arra fókuszálva, hogy a befektetőknek milyen nehézségekkel kell szembenézniük [EbbersZhang, 2010]. A szerzők megállapították, hogy az EU-ban meglévő kínai tőke meglehetősen alacsony a világ többi régiójához képest. Az okok egyrészt arra vezethetők vissza, hogy a fejlődő országok nagyobb hangsúllyal szerepelnek a célországok között, másrészt a kínai befektetőknek több nehézséggel kell szembenézniük, mint bárhol máshol a világon. Az adóösztönzők megléte rendkívül fontos a kínai befektetők számára. Az FDI beáramlás gördülékennyé tétele érdekében a közép-kelet-európai országok jelentősen átgondolták fiskális politikájukat, melynek eredményeként számos adózási könnyítést vezettek be. Az intézkedések magukba foglalták az adómentességet (tax concession), a szabadkereskedelmi zónák felállítását és a kettős adóztatás elkerülésének lehetőségét. A kínai befektetők elvárásaival összhangban az egyes országok és Kína között kétoldalú adójogi megállapodások születtek.

Casaburi átfogó felmérésében a Spanyolországban működő kínai vállalatok 17 üzleti környezetre vonatkozó változót rangsoroltak, melyek közül az egyik az adórendszerre vonatkozott ${ }^{18}$ [Casaburi, 2015]. A hat kategória ${ }^{19}$ közül az adózás kapta a legalacsonyabb értéket, mely két alkategóriát ${ }^{20}$ foglalt magába. Az eredmények azt sugallják, hogy az adózás a fejlesztendő területek közé tartozik. Összességében a kínaiak benyomása a spanyol üzleti klímáról pozitívnak bizonyult és még némileg javult is az elmúlt évek során.

14 p. 14.

15 Főbb motiváló erők: helyi piacokhoz való hozzáférés; helyi üzleti partner; technológia; munkaerő; adózási, ösztönzési és támogatási rendszer; logisztika; kulturális és nyelvi sajátosságok.

16 p. $22-23$.

17 p. 33.

18 p. 74.

19 Adózás, infrastrutúra minősége, humán erőforrás, költségek, szabályozás, piac.

20 Adóteher, társasági adó. 
A legtöbbre a spanyol munkaerőt értékelték, mellyel összefüggésben a dolgozók végzettsége, elérhetősége és Kínához való hozzáállása mind magas osztályzatot kapott.

Katona a magyarországi adókedvezmények hatásait vizsgálta ${ }^{21}$ [Katona, 2012]. A társasági adó esetében az empirikus kutatások nem támasztották alá azt az elméleti felvetést, mely szerint az adóösztönzők jelentősen javítottak volna Magyarország, illetve a régió tőkevonzó képességén. A rendszerváltás óta eltelt időszakban a társasági adó jelentősen mérséklődött, azonban a folyamat nem gyakorolt jelentős hatást az FDI volumenére és a termelékenységre. Kutatásaiból az tűnik ki, hogy a cégeknél nagyobb hangsúlyt kapott a szakképzettség megléte, melynek következtében a magasabb bérszínvonalon foglalkoztatott kvalifikált dolgozók nagyobb kibocsátásra voltak képesek.

\section{KORRELÁCIÓ-ANALÍZIS}

Az elemzés döntő többségében az Eurostat adatbázisára épült, biztosítva ezzel a hasonló statisztikai módszertant és az országok közötti összehasonlíthatóságot. Függő változónak a kínaiak által befektetett működőtőke-állomány felelt meg. A kutatás eredményei csak bizonyos megkötésekkel fogadhatóak el. Korlátai között mindenképpen meg kell említeni, hogy a külföldi müködőtőkéről csak 2001 óta állnak rendelkezésre információk és a rövid időtartamból nehezen vonhatók le végleges következtetések. A választott módszertan erősen függött a lehetőségektől és a megfigyelések alacsony száma miatt kizárólag korrelációs analízis használata volt szakmailag indokolt.

Általános forgalmi adó. Annak ellenére, hogy az Európai Unióban viszonylag harmonizált adónemről van szó, az egyes országokban jellemző az eltérő kulcsok alkalmazása. Az ösztönzők között megemlítendő a bizonyos termékekre, szolgáltatásokra nyújtott áfamentesség. Mivel a központi költségvetés legnagyobb adóbevétele ebből az adónemből származik, ezért kiemelten fontos területről van szó. A forgalmi adózás harmonizációja már az 1960-as években elkezdődött, de teljes mértékben a mai napig sem fejeződött be [Ódor, 2009]. Az okok között megemlíthető, hogy a tagállamok vonakodnak egységesebb adórendszert kialakítani, figyelmen kívül hagyva a közösségi rendelkezéseket. Jelenleg kérdéses, hogy megvalósul-e valaha is a teljes adóharmonizáció, mely lényegében versenysemleges környezetet teremtene az EU összes tagállamában, mivel hasonló kulcsok és számítás lenne használatban.

$\mathrm{Az}$ alábbi táblázatban látható, hogy az áfabefizetés aránya a központi költségvetés teljes adóbevételéhez viszonyítva jelentősen eltér a régió egyes országai között. A legalacsonyabb értéket Csehországban regisztrálták, mely az elmúlt időszakban 20 százalék körül alakult, míg Horvátországban az arány a 60 százalékot is meghaladja. A vizsgált időszakban az egyes tagállamok áfabevételének részaránya évröl évre hasonlóan alakult, jelentős kilengések nem voltak tapasztalhatók. Ebből arra lehet következtetni, hogy az adóverseny az áfa esetében kevésbé érezteti hatását és ez az adónem a központi költségvetésnek továbbra is jelentős bevételi forrását képezi. 
1. táblázat: Az általános forgalmi adó a központi költségvetés összes adóbevételéhez viszonyítva Közép-Kelet-Európában (\%), 2002-2015

\begin{tabular}{|c|c|c|c|c|c|c|c|c|c|c|}
\hline Ország & $\mathbf{2 0 0 6}$ & $\mathbf{2 0 0 7}$ & $\mathbf{2 0 0 8}$ & $\mathbf{2 0 0 9}$ & $\mathbf{2 0 1 0}$ & $\mathbf{2 0 1 1}$ & $\mathbf{2 0 1 2}$ & $\mathbf{2 0 1 3}$ & $\mathbf{2 0 1 4}$ & $\mathbf{2 0 1 5}$ \\
\hline Bulgária & 49,3 & 43,0 & 46,8 & 44,4 & 46,8 & 45,9 & 47,3 & 46,8 & 45,6 & 44,5 \\
\hline Csehország & 18,1 & 17,7 & 19,6 & 20,7 & 20,6 & 20,2 & 21,1 & 21,8 & 22,7 & 22,0 \\
\hline Észtország & 34,9 & 33,3 & 30,1 & 30,2 & 31,8 & 32,1 & 32,6 & 31,6 & 32,2 & 32,9 \\
\hline Horvátország & 56,5 & 55,8 & 56,9 & 56,3 & 57,2 & 58,0 & 61,1 & 61,0 & 61,5 & 60,8 \\
\hline Lengyelország & 44,6 & 43,5 & 41,7 & 43,3 & 43,6 & 44,7 & 42,4 & 42,7 & 43,5 & 42,4 \\
\hline Lettország & 50,9 & 50,5 & 43,0 & 45,0 & 49,5 & 49,5 & 49,7 & 50,4 & 50,4 & 50,5 \\
\hline Litvánia & 36,5 & 38,9 & 38,2 & 41,8 & 47,7 & 49,4 & 47,6 & 46,9 & 46,8 & 45,4 \\
\hline Magyarország & 35,4 & 34,8 & 31,2 & 34,2 & 36,4 & 38,8 & 39,2 & 38,9 & 39,9 & 41,0 \\
\hline Románia & 42,7 & 42,9 & 42,9 & 39,0 & 43,4 & 47,7 & 46,8 & 46,5 & 43,1 & 43,1 \\
\hline Szlovákia & 42,7 & 38,6 & 40,2 & 41,4 & 40,0 & 41,8 & 38,7 & 38,7 & 38,4 & 37,9 \\
\hline Szlovénia & 39,7 & 40,9 & 42,4 & 42,9 & 43,8 & 44,5 & 43,7 & 45,8 & 45,3 & 43,9 \\
\hline
\end{tabular}

Forrás: Eurostat

A korrelációs analízis eredményei alapján megállapítható, hogy a régióban az áfa mértéke nem befolyásolta a kínai döntéshozókat. Az egyedüli ország, ahol érvényes korreláció figyelhető meg az Magyarország volt, ahol a központi költségvetés áfabevételének GDP-hez viszonyított értéke és a kínai müködőtőke-állomány között szoros kapcsolat alakult ki. Az áfabefizetés a központi költségvetés bevételéhez viszonyítva hasonló eredményekkel járt azzal a különbséggel, hogy itt a magyar korreláció közepesnek bizonyult. Magyarországon az elmúlt időszakban növekedtek az áfakulcsok, amely a GDP arányos áfabevételnél is éreztette hatását, viszont az adóemelés ellenére a kínai befektetési kedv töretlennek bizonyult. A szlovák áfa súlyának mérséklödése az adószerkezeten belül hozzájárulhatott az elmúlt két évben megjelenő kínai tőkebefektetések felélénküléséhez.

Társasági adó. A közvetett adókkal ellentétben nem létezik egységes közösségi jogalkotás a közvetlen adókra vonatkozóan, melynek megfelelően a gyakorlatban a döntéshozók csak irányelvekkel, valamint ajánlásokkal próbálnak meg érvényt szerezni az adóharmonizációs követelményeknek [Galántainé, 2005]. A társasági adónál tehát nagyobb az egyes államok szabadsága, ugyanakkor a tagállamoknak biztosítaniuk kell a diszkriminációmentességet, a versenyszabadságot, valamint be kell tartaniuk a szubvenciókra vonatkozó EU-s elöírásokat is. Az adóverseny elötérbe kerülése miatt az EUban és a világon is viszonylag széles a társasági adókulcsok skálája.

A lenti táblázat arról árulkodik, hogy Magyarország és Szlovákia kivételével az elmúlt tíz évben vagy stagnáltak, vagy csökkentek a társasági adókulcsok. A régióra jellemző, 
hogy a nyugati országokhoz képest a közvetlen ${ }^{22}$ adóbevétel kisebb, a közvetett ${ }^{23}$ adóbevétel nagyobb arányt képvisel a régió adószerkezetében, mely lényegében azt jelenti, hogy a verseny következtében kieső közvetlen adóbevételeket közvetett adók beszedésével próbálják meg pótolni. A társasági adó erodálódása nemcsak az Európai Unióban, hanem az egész világon jellemző tendencia.

2. táblázat: A társasági adókulcs alakulása Közép-Kelet-Európában (\%), 2006-2016

\begin{tabular}{|c|c|c|c|c|c|c|c|c|c|c|c|}
\hline Ország & $\mathbf{2 0 0 6}$ & $\mathbf{2 0 0 7}$ & $\mathbf{2 0 0 8}$ & $\mathbf{2 0 0 9}$ & $\mathbf{2 0 1 0}$ & $\mathbf{2 0 1 1}$ & $\mathbf{2 0 1 2}$ & $\mathbf{2 0 1 3}$ & $\mathbf{2 0 1 4}$ & $\mathbf{2 0 1 5}$ & $\mathbf{2 0 1 6}$ \\
\hline Bulgária & 15,0 & 10,0 & 10,0 & 10,0 & 10,0 & 10,0 & 10,0 & 10,0 & 10,0 & 10,0 & 10,0 \\
\hline Csehország & 24,0 & 24,0 & 21,0 & 20,0 & 19,0 & 19,0 & 19,0 & 19,0 & 19,0 & 19,0 & 19,0 \\
\hline Észtország & 23,0 & 22,0 & 21,0 & 21,0 & 21,0 & 21,0 & 21,0 & 21,0 & 21,0 & 20,0 & 20,0 \\
\hline Horvátország & 20,0 & 20,0 & 20,0 & 20,0 & 20,0 & 20,0 & 20,0 & 20,0 & 20,0 & 20,0 & 20,0 \\
\hline Lengyelország & 19,0 & 19,0 & 19,0 & 19,0 & 19,0 & 19,0 & 19,0 & 19,0 & 19,0 & 19,0 & 19,0 \\
\hline Lettország & 15,0 & 15,0 & 15,0 & 15,0 & 15,0 & 15,0 & 15,0 & 15,0 & 15,0 & 15,0 & 15,0 \\
\hline Litvánia & 15,0 & 15,0 & 15,0 & 20,0 & 15,0 & 15,0 & 15,0 & 15,0 & 15,0 & 15,0 & 15,0 \\
\hline Magyarország & 16,0 & 16,0 & 16,0 & 16,0 & 19,0 & 19,0 & 19,0 & 19,0 & 19,0 & 19,0 & 19,0 \\
\hline Románia & 16,0 & 16,0 & 16,0 & 16,0 & 16,0 & 16,0 & 16,0 & 16,0 & 16,0 & 16,0 & 16,0 \\
\hline Szlovákia & 19,0 & 19,0 & 19,0 & 19,0 & 19,0 & 19,0 & 19,0 & 23,0 & 22,0 & 22,0 & 22,0 \\
\hline Szlovénia & 25,0 & 23,0 & 22,0 & 21,0 & 20,0 & 20,0 & 18,0 & 17,0 & 17,0 & 17,0 & 17,0 \\
\hline Európa & 23,7 & 23,0 & 22,0 & 21,6 & 21,5 & 20,8 & 20,4 & 20,6 & 19,7 & 20,1 & 20,5 \\
\hline Európai Unió & 24,8 & 24,0 & 23,2 & 23,1 & 22,9 & 22,7 & 22,5 & 22,8 & 21,3 & 22,3 & 22,1 \\
\hline OECD & 27,7 & 27,0 & 26,0 & 25,6 & 25,7 & 25,4 & 25,2 & 25,3 & 24,1 & 24,9 & 24,9 \\
\hline Világ & 27,5 & 27,0 & 26,1 & 25,4 & 24,7 & 24,5 & 24,4 & 23,7 & 23,6 & 23,9 & 23,6 \\
\hline
\end{tabular}

Forrás: KPMG

Hasonlóan az általános forgalmi adóhoz, a társasági adó alakulása szintén nem számított meghatározó tényezőnek a kínai befektetések szempontjából. Magyarország, Észtország és Szlovákia kivételével a régióban nem érződött az adóverseny pozitív hatása, mely mutatja, hogy a befektetők nem a TAO alakulása alapján hozzák meg döntéseiket. Magyarországon és Szlovákiában a TAO magyarázó ereje jelentősnek, Ėsztországban közepesnek volt mondható. A növekvő adókulcsok ellenére Magyarországon a társasági

22 Személyi jövedelemadó, társasági adó.

23 Általános forgalmi adó, jövedéki adó. 
adóbefizetések aránya mérséklődni látszik mind a GDP, mind a teljes adóbefizetés arányában. Megfigyelhető viszont, hogy a magasabb társasági adó mérték sem törte meg a kínai befektetési kedvet. Szlovákia nem tartozik a leginkább kiemelt befektetési célpontok közé, azonban a regionális szinten magas adókulcsok ellenére az elmúlt két évben mutatkozott némi kínai érdeklődés az ország iránt. Észtországban a GDP és a központi költségvetés bevételeihez viszonyított mutató csökkenő tendenciát mutat, amely elsősorban a gazdasági világválság utáni években figyelhető meg igazán. Az észt társasági adó csökkenő súlyának ellenére a kínai működőtőke-állomány 2012 és 2014 között folyamatos csökkenésen esett át.

\section{KöVETKEZTETÉSEK}

Az adóverseny és a külföldi tőkebeáramlás kapcsolata viszonylag széles körben kutatott téma. A közép-kelet-európai régió a rendszerváltás óta rendkívül nagy hangsúlyt fektetett a FDI beáramlásra. A célok eléréséhez használt egyik eszköz az adórendszer átalakítása volt, melynek eredményeként megindult a társasági adó erodálódásának folyamata. A tagállamok közötti adóverseny során a különböző kedvezmények egyre nagyobb mértéket és változatosabb formát öltöttek. Az ilyen jellegü gazdaságpolitika eredménye az lett, hogy a közép-kelet-európai országok túlságosan függővé váltak a külföldi tőkétől, azonban kérdéses, hogy kizárólag külső beruházásokra épülve sikerülhet-e a gazdasági felzárkózás. Mindenesetre a nyugat-európai országok példái azt igazolják, hogy erős hazai iparágak nélkül nem képzelhető el tartós gazdasági növekedés.

A szakirodalom azt támasztja alá, hogy az adózás fontos, de nem elégséges feltétele a FDI beáramlásnak. Elsősorban a tőkehiánnyal markánsabban küzdő közép-kelet-európai országok versenyképességén javíthatnak a cégeknek nyújtandó adókedvezmények. Korábban a kínai befektetők jelentős tőkét helyeztek ki adóparadicsomokba, mára azonban teret kaptak a fejlett országokba történő befektetések is. A jelenség azt sugallja, hogy a világ fejlettebbik részén az adózás ma már kevésbé fontos szerepet tölt be a tőkeáramlásban. Az adóterhek csökkentése továbbra is motiváló tényező, viszont a vállalkozásokat sokszor nem maga az adó mértéke, hanem az egyes tagállamok eltérő adórendszere aggasztja. Amennyiben a nagyobb volumenü adófizetés magasabb szintü állami intézményrendszerrel és kiszámítható, biztonságpolitikai-gazdasági környezettel párosul, akkor az adózás nem feltétlenül értelmezhető negatív jelenségként.

$\mathrm{Az}$ adóharmonizáció kontra adóverseny konfliktus feloldása rendkívül nehéz feladat. Az adórendszer az egyes államok nemzeti szuverenitását is jelenti, melynek keretén belül szívesen élnek a fiskális könnyítésekkel, viszont az adóharmonizáció elengedhetetlen az EU versenyképességének erősítése szempontjából. Az adózás esetében kérdés, hogy a közös európai valutához hasonlóan megvalósítható-e a teljes harmonizáció, illetve egyáltalán szükség van-e ilyen mértékủ lépésekre, vagy bizonyos pontokban nagyobb teret érdemes engedni a nemzeti érdekeknek. Az adóverseny szembe megy az EU adóharmonizációs törekvéseivel, melynek célja az áruk, a szolgáltatások, a munkaerő és a tőke szabad mozgásának biztosítása. A fent bemutatott eredmények mindenesetre megkérdőjelezik az adóverseny létjogosultságát, mivel érvényes korreláció csak Észtországban, Magyarországon és Szlovákiában mutatható ki. Az eredmények arra engednek 
következtetni, hogy a befektetők egyéb makrogazdasági szempontok alapján hozzák meg döntéseiket, melyek feltárása további kutatások tárgya lehet.

\section{FelHASZnÁlt irodalom}

Bellak, C. - Leibrecht, M. (2005): „Do low corporate income tax rates attract FDI? Evidence from Eight Central- and East European Countries." Applied Economics 41(21): 2691-2703.

Beyer, J. (2002): "'Please invest in our country” how successful were the tax incentives for foreign investment in transition countries?" Communist and Post-Communist Studies 35(2): 191-211.

Casaburi, I. (2015): Chinese investment in Europe 2015-16. ESADE China Europe Club, Barcelona

Clausing, K. A. - Dorobantu, C. L. (2005): „Re-entering Europe. Does European Union candidacy boost foreign direct investment?" Economics of Transition 13(1): 77103.

Ebbers, H. - Zhang, J. (2010): „Chinese investments in the EU.” Eastern Journal of European Studies 1(2): 187-206.

Egger, P. - Raff, H. (2011): „Tax Rate and Tax Base Competition for Foreign Direct Investment." Kiel Working Papers No. 1734, 50 p.

European Union Chamber of Commerce in China (2013): Chinese Outbound Investment in the European Union. European Union Chamber of Commerce in China, Peking

Eurostat: Statistics, http://epp.eurostat.ec.europa.eu/portal/page/portal/eurostat/home/ Galántainé, M. Zs. (2005): „Adóverseny az Európai Unióban.” Hitelintézeti Szemle 4(56): $45-62$.

Garcimartín, C. - Garrido, M. P. - Anchuelo, Á. (2011): „Can tax incentives be detrimental to FDI? The role of institutions." Papeles de trabajo del Instituto de Estudios Fiscales, Serie economía 14(8): $18 \mathrm{p}$.

Grzegorczyk, L. - Budzynski, T. (2015): „The rate of corporate income tax and the investment attractiveness of the Visegrad Group countries." In: Dermol, V. - Trunk, A. - Smrkolj, M. (szerk.): Managing Intellectual Capital and Innovation for Sustainable and Inclusive Society, MakeLearn and TIIM Joint International Conference, Bari, Olaszország, 2015. május 27-29.

Hansson, A. - Olofsdotter, K. (2010): „Tax differences and foreign direct investment in the EU27." Department of Economics, Lund University, Working Papers No. 2010(3): 1-34.

Katona, K. (2012): „Az adópolitika hatása mikroökonómiai szemszögből. Vállalati termelékenység Magyarországon." Pázmány Law Working Papers 3(25): 1-18 .

Kersan-Skabic, I. (2015): „The Importance of Corporate Taxation for FDI Attractiveness of Southeast European Countries." Panoeconomicus 62(1): 105-122.

Korniyenko, Y. - Sakatsume, T. (2009): „Chinese investment in the transition countries." EBRD Working Paper No. 107: 33 p.

Központi Statisztikai Hivatal: STADAT, http://www.ksh.hu/stadat 
KPMG: Corporate tax rates table, https://home.kpmg.com

Ódor, Cs. (2009): „A forgalmi adó szabályozása az EU-ban.” De iurisprudentia et iure publico 3(2): $16 \mathrm{p}$.

Popovici, O. C. (2012): „Is taxation affecting the attractiveness of Central and Eastern Europe countries for FDI?” Annals of the "Constantin Brancusi” University of Targu Jiu, Economy Series 1(1): 141-145.

Sedmihradsky, M. - Klazar, S. (2002): „Tax competition for FDI in Central-European countries." CESifo Working Paper Series No. 647: 8 p.

Woodward, D. P. - Rolfe, R. J. - Guimaraes, P. - Doupnik, T. (2000): „Taxation and the Location of Foreign Direct Investment in Central Europe." In: Fatemi, K. (szerk.): The New World Order. Internationalism and the Multinational Corporations. Pergamon Press, Oxford

\section{MeLLÉKLETEK}

1. melléklet: A korreláció-analízis eredményei, 2001-2015

\begin{tabular}{|c|c|c|c|c|c|c|c|c|}
\hline \multirow[t]{2}{*}{ Ország } & \multicolumn{2}{|c|}{$\begin{array}{c}\text { Általános } \\
\text { forgalmi adó / } \\
\text { GDP }\end{array}$} & \multicolumn{2}{|c|}{$\begin{array}{c}\text { Általános } \\
\text { forgalmi adó/ } \\
\text { Összes adó }\end{array}$} & \multicolumn{2}{|c|}{$\begin{array}{c}\text { Társasági adó } \\
\text { / GDP }\end{array}$} & \multicolumn{2}{|c|}{$\begin{array}{c}\text { Társasági adó / } \\
\text { Összes adó }\end{array}$} \\
\hline & $\mathbf{R}^{2}$ & p-érték & $\mathbf{R}^{2}$ & p-érték & $\mathbf{R}^{2}$ & p-érték & $\mathbf{R}^{2}$ & p-érték \\
\hline Bulgária & 0,01 & 0,77 & 0,00 & 0,84 & 0,08 & 0,30 & 0,11 & 0,23 \\
\hline Csehország & 0,08 & 0,31 & 0,11 & 0,23 & 0,07 & 0,34 & 0,06 & 0,38 \\
\hline Észtország & 0,06 & 0,38 & 0,00 & 0,81 & 0,51 & 0,01 & 0,55 & 0,01 \\
\hline Lengyelország & 0,12 & 0,21 & 0,01 & 0,74 & 0,10 & 0,25 & 0,05 & 0,44 \\
\hline Litvánia & 0,18 & 0,12 & 0,01 & 0,72 & 0,11 & 0,22 & 0,09 & 0,29 \\
\hline Magyarország & 0,77 & 0,00 & 0,33 & 0,02 & 0,35 & 0,02 & 0,42 & 0,01 \\
\hline Románia & 0,12 & 0,29 & 0,21 & 0,16 & 0,26 & 0,11 & 0,30 & 0,08 \\
\hline Szlovákia & 0,01 & 0,77 & 0,37 & 0,03 & 0,80 & 0,00 & 0,71 & 0,00 \\
\hline
\end{tabular}

